\title{
Professional characteristics and teaching competencies of Filipino teachers in China and Philippines: A comparative study
}

\author{
Bagapuro, Arnold $\measuredangle$ \\ Luoyang International School, China (aabagapuro@gmail.com)
}

Delos Santos, Ma. Ruby Hiyasmin

Central Luzon State University, Philippines (hiyasminmalicdem@clsu.edu.ph)

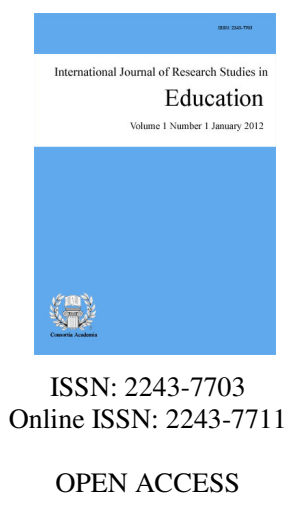

Received: 28 December 2020

Revised: 22 February 2021

Available Online: 17 March 2021

DOI: $10.5861 /$ ijrse.2021.4

Accepted: 7 March 2021

\section{Abstract}

This study was conducted to know the professional characteristics and teaching competencies of Filipino teachers in China and the Philippines. A researcher-made questionnaire was used as the main instrument to generate the needed data. In terms of professional characteristics, most of the respondents in China and the Philippines hold a bachelor's degree, while many in the Philippines hold a master's degree. Most were licensed teachers, and a big group had 6 to 10-year teaching experience. Teachers in the Philippines receive lower salaries, and a disparity in their overtime pay, bonuses and allowances, and leave/medical privileges were noted. Professional development opportunities were also more evident in the Philippines compared to China. Teachers in the Philippines were higher across all the ten teaching competencies. Specifically, creating a Learning Environment has the highest mean for China while Identification of Student's Needs and Communication in the Philippines. In China, educational attainment and monthly salary have a highly significant relationship to teaching competencies. It is comparable to the Philippines, wherein educational attainment was also significantly related to teaching competencies and monthly salary. Finally, it was found that respondents in the Philippines had higher teaching competencies, particularly on varied teaching strategies, collaboration, and commitment to the profession.

Keywords: professional characteristics; teaching competencies; China; Philippines; Filipino teachers 


\section{Professional characteristics and teaching competencies of Filipino teachers in China and Philippines: A comparative study}

\section{Introduction}

Teachers are important components of the educational system. They dispense information using different methods and strategies, become caring adults to their students, and serve as motivators that drive the learners to become creators of knowledge. Apart from lecturing students, they also provide a rewarding and unique teaching and learning experience.

Research has shown that teachers' actions in their classrooms have twice the impact on student achievement as do school policies regarding curriculum, assessment, staff collegiality, and community involvement (Marzano, as cited in Marzano \& Marzano, 2003, p. 1). Rice (2003) also noted that teacher quality matters. It is the most important school-related factor influencing student achievement. Thus, professional characteristics are important considerations in an effective teaching and learning process. They are significant to the learners for it shall affect or determine the outcome of the job these educators were doing. As the world is changing, trends in education go along with these changes to meet the needs of the 21 st century learners. Hence, they move from the traditional teaching methodologies to a more inclusive and collaborative teaching and learning process.

With respect to changes in the educational system, development of teacher education, scientific results of educational science and other fields, teachers' competencies have been taken into consideration along with professional characteristics. As defined by Shukla (2014), teaching competencies include the acquisition and demonstration of the composite skills required for student teaching like introducing a lesson, fluency in questioning, probing questions, explaining, pace of lesson, reinforcement, understanding child psychology, recognizing behavior, classroom management and giving assignment. To maximize learning, teachers at any level requires a significant amount of knowledge and skill. Paying attention to the core competencies of teachers warrants a positive experience for students and their families (Zeiger, 2018).

Through the years, Filipino teachers have practiced their profession in other countries. In an article of Business Mirror (2018), these educators were described as caring, dedicated and had become so good in their career that some of them are now recognized worldwide as the best in their field. The People's Republic of China is one of these countries where Filipinos teach English in particular as well as other in-depth subjects like math, sciences, and literature. In the advent of globalization, China found itself promoting internationalism thus, the Ministry of Education pushed its citizens or at least the new generations to learn English. In the next years to come, the government is expecting that all employees under 40 years old would be able to master not less than 1,000 English phrases and to be used in all its agencies. As a matter of fact, all kindergarten schools began teaching English to the student as young as two years old. Also, extensive funding from the government was allotted for teachers' training program and to the research and development of new ways in language learning skills. For this reason, a "mania" about learning English had boomed in the country resulting to different educational institutions offering English classes. This opened a high demand for English teachers, native or non-native speakers.

In the Philippines, the career in education has become one of the prominent professions throughout history. Though Filipino teachers are in demand abroad, many still opt to stay in the country, develop their professional characteristics and enhance their teaching competencies in the different private and public institutions. Their salary may not be as competitive as those teaching abroad, yet serving the Filipino children has become their main source of inspiration to stay behind.

The proliferation of Filipino teachers in China cannot be denied especially with the warming diplomatic 
relationship of China and the Philippines and the rising demands of China for Filipino teachers. Nevertheless, it is imperative that Filipino teachers analyze and consider some major factors between teachers in China and the Philippines especially in terms of professional characteristics and teaching competencies which are sometimes less considered factors. Hence, the purpose of this study is to give a comparison of these two important variables in the teaching profession. most especially on the verge of 21 st-century teaching and learning.

Specifically, the researchers attempted to answer the following objectives:

$>\quad$ compare the professional characteristics of Filipino teachers in China and the Philippines in terms of educational preparation, benefits and professional development opportunities (training and scholarship programs);

$>$ compare their teaching competencies such as interaction with students, creation of a learning environment, lesson planning, use varied teaching strategies, assessment, identification of student's needs, communication, collaboration, maintaining a professional appearance, and commitment to the profession;

$>\quad$ find out the relationship between the respondents' professional characteristics and their teaching competencies;

$>\quad$ find out the difference between the teaching competencies of the respondents in the Philippines and China.

\section{Materials and methods}

This study utilized descriptive and comparative research design which involved describing and analyzing the respondents' professional characteristics and teaching competencies across the different areas. After which, a comparison across these variables was made to see the similarities and differences.

\subsection{Participants}

One hundred sixty-three (163) Filipino teachers were purposively chosen to take part in the study (83 from China and 80 from the Philippines). Respondents for both countries were mostly (77.91\%) females wherein China has the higher number of female teachers with 81.93 percent compared to 73.75 percent in the Philippines. On the other hand, respondents were of different age ranges but many (44.79\%) of them were 21 to 30 years old. They were mostly single $(57.06 \%)$ however, more $(61.45 \%)$ single teachers were noted in China than in the Philippines $(52.5 \%)$. When it comes to employment status, 66.87 percent were full-time teachers wherein there are more $(72.5 \%)$ respondents in the Philippines serving full-time in their respective institutions than in China $(61.45 \%)$. For the type of school where the respondents are currently teaching, private schools obtained the highest percentage $(73.62 \%)$. One hundred percent of the teachers in China work in private schools while in the Philippines, only $46.25 \%$ were connected to private institutions.

For both China and Philippines, the researchers sent a written communication to the Principal/School Head to seek for approval to allow Filipino teachers to take part in the study. The letter to School Principals in China was written in Chinese. Also, a formal letter was individually sent to each respondent, bearing the nature and purpose of the study. Participation was voluntary and through the initiative of the teachers. The researchers respected if respondents decline the invitation to participate.

\subsection{Procedure}

A three-part researcher-made questionnaire was used as the main instrument for gathering the data. Part I drew figures on the socio-demographic characteristics, Part II contained information on the professional characteristics such as educational preparation (educational attainment, eligibility and years of experience), 
benefits and privileges (monthly salary, overtime pay, bonuses and allowances, leave privileges, and medical benefits), and professional development opportunities (trainings and scholarship programs). Meanwhile, Part III was a 50-item checklist about teaching competencies using the ten (10) core competencies presented by Zeiger (2018). Each core competency was described by five (5) parameters or statements. In order for the respondents to rate the parameters/statements according to how it was applied to them, they were asked to select from four response choices with a corresponding scale value specifically: 4 - always true of me, 3 - often true of me, 2 seldom true of me, and $1-$ never true of me. The questionnaires were personally distributed to the respondents and they were given around 15 to 20 minutes to provide their answers. After which, the questionnaires were collected and responses were encoded for data analysis.

\subsection{Data analysis}

To test the reliability of the research instrument, the internal consistency method was utilized using the Cronbach's alpha. The research instrument obtained a coefficient value of 0.83 suggesting that the items have relatively high internal consistency. It was also content validated by four licensed professional teachers who are considered experts in the field of education (two classroom teachers, one master teacher and one school principal) to ensure that all parameters/statements were aligned to the core competencies. The conceptual paradigm illustrated in Figure 1 presents the comparison of the variables in the study. It includes the professional characteristics as well as teaching competencies. The framework further shows the hypothesized relationship between professional characteristics and teaching competencies.

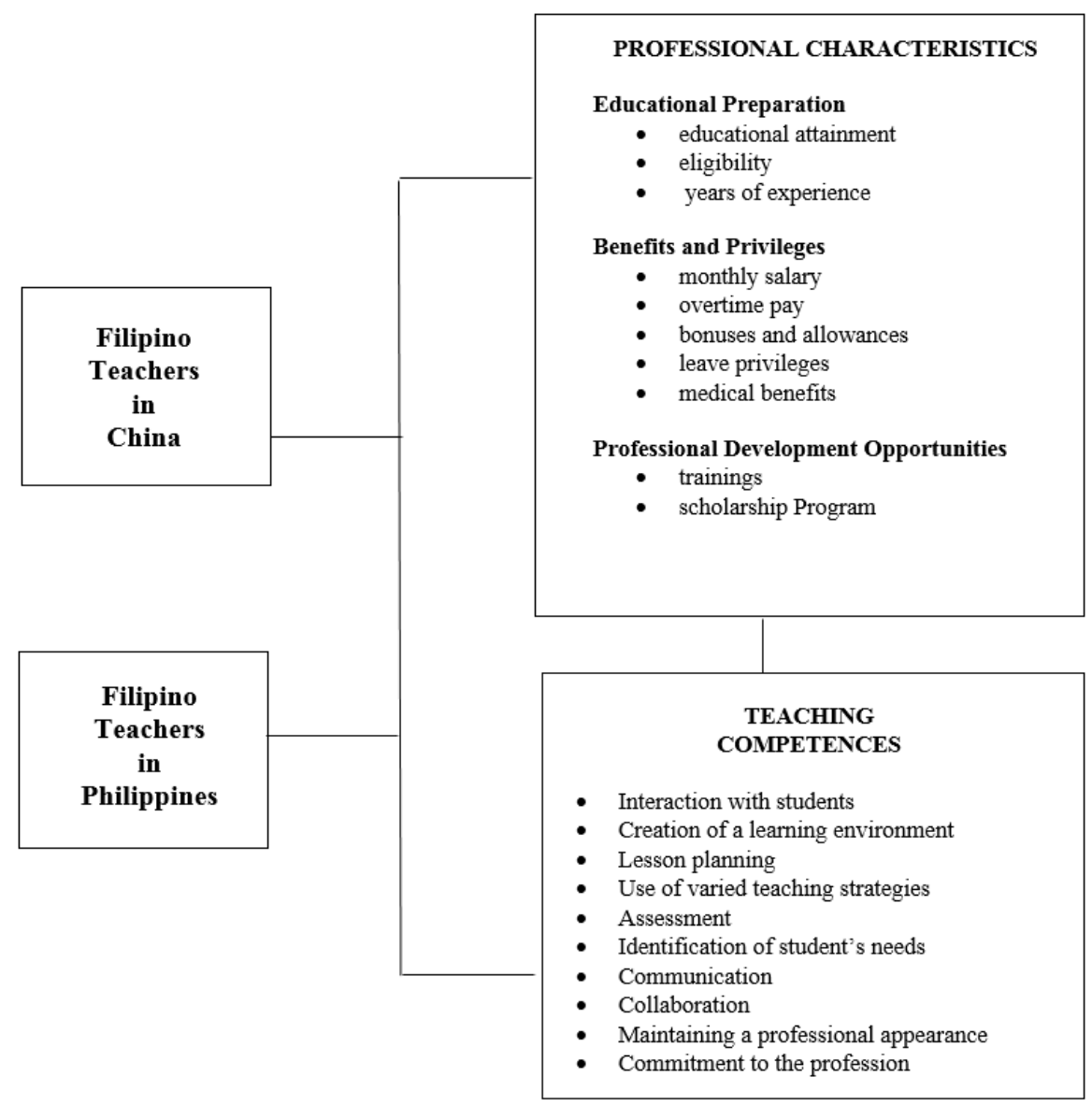

Figure 1. Conceptual paradigm showing the relationship of the variables in the study

\section{Results}

This section presents the write-up of each variable which includes the professional characteristics, teaching

66 Consortia Academia Publishing (A partner of Network of Professional Researchers and Educators) 
competencies, relationship between professional characteristics and teaching competency, and difference between the teaching competencies of Filipino teachers in China and Philippines.

\subsection{Professional characteristics}

Professional characteristics refer to the educational preparation, benefits and privileges and other professional development opportunities received by the respondents. Results in Table 1 revealed that in terms of educational attainment, most (71.78\%) teachers in China and Philippines were bachelor's degree holders, however a higher percentage (87.95\%) was observed with teachers teaching in China than the Philippines (55\%). This is because after completing their bachelor's degree, teachers in the Philippines took up graduate programs. Hence, 43. 75 percent and 1.25 percent of them were master's degree and Doctor of Philosophy holders, respectively compared to teachers in China wherein only $12.05 \%$ were master's degree holders. No one among them has a Doctor of Philosophy degree.

When it comes to eligibility, most $(80.89 \%)$ are licensed professional teachers with a higher percentage (92.5\%) from respondents in the Philippines compared to $69.88 \%$ in China. Other respondents have civil service eligibility (9.64\% in China and $1.25 \%$ in the Philippines), teaching certificate $(6.02 \%$ in China and $2.5 \%$ in the Philippines) while $14.24 \%$ and $3.75 \%$ in China and Philippines, respectively did not have any eligibility aside from their educational preparation.

In terms of years of experience, majority (38.65\%) has between 6-10 years of teaching experience for all the respondents. For teachers in China, many (48.19\%) of them also have 6 to 10 years of experience whereas, in the Philippines, there were more (38.75\%) teachers with 1 to 5 years of experience. Meanwhile, when it comes to benefits and privileges, 46.01 percent of the respondents receive a salary of Php 35,000 pesos above. These respondents were all teachers in China while in the Philippines, majority (43.75\%) receive below Php 10,000 pesos a month. In fact, no one receives a salary amounting to above Php 30,000 pesos. In connection to this, 94.48 percent of all the respondents do not receive overtime pay for works made beyond office hours, however a higher percentage was seen in the Philippines (98.75\%) compared to China (90.36). In China, 9.64 percent of the teachers were given overtime pay by their employers while only 1.25 percent in the Philippines. In addition, 74.85 percent of respondents from China and Philippines receive bonuses and allowances in which a higher percentage (78.75\%) comes from the Philippines compared to 71.08 percent in China. Also, 57.67 percent of all the respondents declared that they have no leave/medical privileges wherein the percentage is higher in the Philippines (76.25\%) than in China (39.76\%).

For professional development opportunities, 34.36 percent of all the respondents agree that they were given training development program that will enhance their skills and competencies as teachers. Comparing the two countries, teachers in the Philippines strongly agree (36.35\%) that their schools provide opportunities that will keep them abreast with the latest trend and developments in the teaching profession while in China, a great number of respondents only agreed (36.14\%) that their schools have training development program for them. In terms of scholarship opportunities, 32.51 percent of all the respondents agreed that the institutions where they are currently working has scholarship programs available for them. Majority $(38.75 \%)$ of the teachers in the Philippines also agree on the matter while in China, most (32.53\%) of the respondents disagreed. This implies that only a limited number of scholarship grants are offered to them.

\subsection{Teaching competencies}

The first competency which was tested among the respondents was their interaction with students. Table 2 showed that those in China scored an overall mean of 3.62 which was lower than the respondents in the Philippines ( $x=3.75$ ). It implied that the respondents were able to interact positively with all types of students with different learning styles while treating them with respect and equal opportunities to learn and grow. However, a higher mean score from the respondents in the Philippines denotes that this competency was well 
Bagapuro, A., \& Delos Santos, M. R. H.

utilized by teachers teaching in Philippine schools.

Table 1

Professional characteristics of the respondents

\begin{tabular}{|c|c|c|c|c|c|c|}
\hline \multirow[t]{2}{*}{ Professional Characteristics } & \multicolumn{2}{|c|}{$\begin{array}{c}\text { Filipino Teachers in } \\
\text { China } \\
n=83\end{array}$} & \multicolumn{2}{|c|}{$\begin{array}{c}\text { Filipino Teachers in } \\
\text { Philippines } \\
n=80\end{array}$} & \multicolumn{2}{|c|}{$\begin{array}{c}\text { TOTAL } \\
\text { (China and Philippines) } \\
n=163\end{array}$} \\
\hline & $f$ & $\%$ & $f$ & $\%$ & $f$ & $\%$ \\
\hline \multicolumn{7}{|c|}{ Educational Preparation } \\
\hline \multicolumn{7}{|l|}{ Educational Attainment } \\
\hline Bachelor's Degree & 73 & 87.95 & 44 & 55.00 & 117 & 71.78 \\
\hline Master's Degree & 10 & 12.05 & 35 & 43.75 & 45 & 27.61 \\
\hline Doctor of Philosophy & 0 & 0 & 1 & 1.25 & 1 & 0.61 \\
\hline \multicolumn{7}{|l|}{ Eligibility } \\
\hline None & 12 & 14.46 & 3 & 3.75 & 15 & 9.20 \\
\hline Civil Service & 8 & 09.64 & 1 & 1.25 & 9 & 5.52 \\
\hline Teaching Certificate & 5 & 06.02 & 2 & 2.5 & 7 & 4.29 \\
\hline Licensed & 58 & 69.88 & 74 & 92.5 & 132 & 80.98 \\
\hline \multicolumn{7}{|l|}{ Years of Experience } \\
\hline Below 1 & 3 & 3.61 & 17 & 21.25 & 20 & 12.27 \\
\hline $1-5$ & 15 & 18.07 & 31 & 38.75 & 46 & 28.22 \\
\hline $6-10$ & 40 & 48.19 & 23 & 28.75 & 63 & 38.65 \\
\hline $11-15$ & 15 & 18.07 & 2 & 02.50 & 17 & 10.42 \\
\hline 16 and above & 10 & 12.05 & 7 & 08.75 & 17 & 10.42 \\
\hline \multicolumn{7}{|c|}{ Benefits and Privileges } \\
\hline \multicolumn{7}{|l|}{ Monthly Salary } \\
\hline Below 10,000 & 0 & 0 & 35 & 43.75 & 35 & 21.47 \\
\hline $10,001-15,000$ & 0 & 0 & 17 & 21.25 & 17 & 10.43 \\
\hline $15,001-20,000$ & 0 & 0 & 12 & 15 & 12 & 7.36 \\
\hline $20,001-25,000$ & 5 & 6.02 & 15 & 18.75 & 20 & 12.27 \\
\hline $25,001-30,000$ & 0 & 0 & 1 & 1.25 & 1 & .61 \\
\hline $30,001-35,000$ & 3 & 3.61 & 0 & 0 & 3 & 1.84 \\
\hline 35,000 above & 75 & 90.36 & 0 & 0 & 75 & 46.01 \\
\hline \multicolumn{7}{|l|}{ Overtime Pay } \\
\hline Without pay & 75 & 90.36 & 79 & 98.75 & 154 & 94.48 \\
\hline With pay & 8 & 9.64 & 1 & 01.25 & 9 & 5.52 \\
\hline \multicolumn{7}{|l|}{ Bonus \& Allowance } \\
\hline Without & 24 & 28.92 & 17 & 21.25 & 41 & 25.15 \\
\hline With & 59 & 71.08 & 63 & 78.75 & 122 & 74.85 \\
\hline \multicolumn{7}{|l|}{ Leave/Medical Privileges } \\
\hline No & 33 & 39.76 & 61 & 76.25 & 94 & 57.67 \\
\hline Yes & 50 & 60.24 & 19 & 23.75 & 69 & 42.33 \\
\hline \multicolumn{7}{|c|}{ Professional Development Opportunities } \\
\hline \multicolumn{7}{|l|}{ Training } \\
\hline Strongly Disagree & 18 & 21.69 & 12 & 15.00 & 30 & 18.40 \\
\hline Disagree & 21 & 25.3 & 13 & 16.25 & 34 & 20.86 \\
\hline Agree & 30 & 36.14 & 26 & 32.5 & 56 & 34.36 \\
\hline Strongly Agree & 14 & 16.87 & 29 & 36.25 & 43 & 26.38 \\
\hline \multicolumn{7}{|l|}{ Scholarship Programs } \\
\hline Strongly Disagree & 26 & 31.33 & 11 & 13.75 & 37 & 22.70 \\
\hline Disagree & 27 & 32.53 & 17 & 21.25 & 44 & 26.99 \\
\hline Agree & 22 & 26.51 & 31 & 38.75 & 53 & 32.51 \\
\hline Strongly Agree & 8 & 9.64 & 21 & 26.25 & 29 & 17.79 \\
\hline
\end{tabular}

For the second competency which is the creation of a learning environment, respondents in China obtained an overall mean score of 3.78 while respondents in the Philippines has 3.80. It implies that the respondents were equipped with necessary skills in setting a conducive learning environment by making high expectations from the learners and consistently enforcing the rules and regulations fairly. However, since the respondents in the Philippines gained a higher mean score, the study rolled out that they were more equipped and knowledgeable in exercising this competency. In terms of lesson planning, the overall mean score of 3.69 obtained by the respondents in China showed that they have demonstrated a good skill in lesson plan design. However, respondents in the Philippines with an overall mean score of 3.80 proved that they were more trained in coming up with lesson plans and efficient in delivering them to address the diverse needs of the students.

With regard to using varied teaching strategies, respondents in China generated an overall mean score of 3.41 against 3.79 for teachers in the Philippines. These results show that respondents in the Philippines were

68 Consortia Academia Publishing (A partner of Network of Professional Researchers and Educators) 
more prepared in utilizing and integrating strategies that would help learners in the teaching and learning process. They had shown a level of mastery in integrating various strategies for student with different learning styles. Meanwhile, for assessment, respondents from the Philippines obtained a higher mean score of 3.75 than those from China $(x=3.55)$. This implies that teachers in the Philippines had better skills in developing and using appraisal, evaluation, or tests that will measure the outcomes of student learning. Respondents in China, especially those without a teaching background, would need to learn and design assessment tools to monitor student performance effectively.

Identification of student's need is one of the core duties of a teacher. In terms of this competency, respondents from the Philippines garnered an overall mean score of 3.81 while those from China got a lower mean score of 3.70. These results proved that the teachers were equipped with skills of recognizing the learning needs of their students as well as having an idea of their emotional, physical, psychological, scholastic and even financial needs. Yet, this competency is manifested by teachers from the Philippines than in China. Moreover, when it comes to communication, respondents in China obtained an overall mean score of 3.68 which is quite lower than the mean score of those from the Philippines (3.81). Such results implied that respondents in the Philippines were equipped with effective communication skills. It would appear that communication (either oral or written) was not a major issue between teachers, students, parents, administrators and other stakeholders. Whereas in China, communication may be an obstacle between Filipino teachers and Chinese students. Because of language barrier, there is a tendency that both the teachers and the students will have difficulty in expressing their ideas.

For collaboration, Table 2 indicates that respondents from China was observed to have a lower mean score (3.42) than respondents in the Philippines (3.71). This demonstrates that collaboration was more evident to the teachers in the Philippines. They work in a professional team, build a harmonious relationship with colleagues and students, act as a role model in service and involved in making the school a safe place for everyone. In China, most Chinese teachers don not speak English. As such, most foreign teachers only converse with teachers who speak English as well. Once again, language was a big factor for collaboration to be not fully present among Filipino teachers in China. As to maintaining a professional appearance, the data illustrates that respondents from the Philippines obtained a higher mean score of 3.80 while respondents from China has 3.77 . This signifies that physical appearance as well as personal characteristics of the teachers such as integrity or ethical conduct, service to students, advocacy, decision-making, compliance in any regulation whether at work or as a private citizen is much evident for teachers in the Philippines than in China. School regulations could have an impact on this competency such as the issuance of teacher's uniform in the Philippines against no uniform required for foreign teachers in China.

Lastly, for commitment to the profession, respondents in China showed a lower mean score of 3.54 against the mean score of the respondents in the Philippines which is 3.77 . This denotes that the respondents show commitment in the teaching profession by being receptive to feedback, enhancing content knowledge with the new trends in education, set aside time for educational seminars, attending a formal graduate program and being involved in educational research. However, commitment to the teaching profession was exercised by Filipino teachers working in the Philippines.

\section{Table 2}

Teaching competencies

\begin{tabular}{|c|c|c|c|c|c|}
\hline & \multirow{2}{*}{ Items } & \multicolumn{2}{|c|}{ China } & \multicolumn{2}{|c|}{$\mathrm{PH}$} \\
\hline & & Mean & Des. & Mean & Des. \\
\hline \multicolumn{2}{|c|}{ Interaction with Students } & 3.62 & AT & 3.75 & AT \\
\hline 1 & $\begin{array}{l}\text { Organizes activities for the students to actively participate in } \\
\text { classroom discussions }\end{array}$ & 3.69 & AT & 3.76 & AT \\
\hline 2 & $\begin{array}{l}\text { Analyzes the situation before making sound decisions particularly } \\
\text { in the teaching and learning experience }\end{array}$ & 3.69 & AT & 3.78 & AT \\
\hline 3 & $\begin{array}{l}\text { Believes in the ability of students to succeed in their own } \\
\text { endeavors }\end{array}$ & 3.87 & AT & 3.85 & AT \\
\hline
\end{tabular}


Table 2 ...continued

\begin{tabular}{|c|c|c|c|c|c|}
\hline \multirow{2}{*}{\multicolumn{2}{|c|}{ Items }} & \multicolumn{2}{|c|}{ China } & \multicolumn{2}{|c|}{$\mathrm{PH}$} \\
\hline & & Mean & Des. & Mean & Des. \\
\hline 4 & $\begin{array}{l}\text { Shows students the excitement and professional enthusiasm in } \\
\text { teaching and assisting them }\end{array}$ & 3.84 & AT & 3.81 & AT \\
\hline 5 & $\begin{array}{l}\text { Organizes events that promote interaction among their fellow } \\
\text { student and teacher such as fieldtrips, workshops and a seminar } \\
\text { with a guest speaker for a particular material }\end{array}$ & 3.03 & OT & 3.57 & AT \\
\hline \multicolumn{2}{|r|}{ Creation of a Learning Environment } & 3.78 & AT & 3.8 & AT \\
\hline 6 & Efficiently organizes the class to maximize learning & 3.67 & AT & 3.75 & AT \\
\hline 7 & $\begin{array}{l}\text { Creates appropriate environment for a conducive teaching and } \\
\text { learning }\end{array}$ & 3.76 & AT & 3.86 & AT \\
\hline 8 & $\begin{array}{l}\text { Promotes the full development of students as individuals without } \\
\text { discrimination to race, ethnicity, sex, socio-economic status, } \\
\text { abilities or disabilities }\end{array}$ & 3.83 & AT & 3.8 & AT \\
\hline 9 & Acts with honesty, transparency, responsibility, and fairness & 3.78 & AT & 3.81 & AT \\
\hline 10 & $\begin{array}{l}\text { Makes each student feel that they matter and their ideas are of } \\
\text { value }\end{array}$ & 3.84 & AT & 3.76 & AT \\
\hline \multicolumn{2}{|c|}{ Lesson Planning } & 3.69 & AT & 3.80 & AT \\
\hline 11 & $\begin{array}{l}\text { Prepares daily/weekly lesson plan and submit to the } \\
\text { head/department chair }\end{array}$ & 3.55 & AT & 3.67 & AT \\
\hline 12 & Comes up with lessons that meet students' need & 3.74 & AT & 3.85 & AT \\
\hline 13 & Presents maximum content of the subject matter to the students & 3.69 & AT & 3.79 & AT \\
\hline 14 & $\begin{array}{l}\text { Provides information that allows students to gain deeper } \\
\text { understanding of the subject matter }\end{array}$ & 3.75 & AT & 3.85 & AT \\
\hline 15 & $\begin{array}{l}\text { Presents the content in a clear and logical framework focusing on } \\
\text { the important aspects of the lesson }\end{array}$ & 3.70 & AT & 3.82 & AT \\
\hline \multicolumn{2}{|r|}{ Use Varied Teaching Strategies } & 3.41 & AT & 3.79 & AT \\
\hline 16 & $\begin{array}{l}\text { Uses traditional and non-traditional teaching strategies to help } \\
\text { students with multiple learning styles }\end{array}$ & 3.35 & AT & 3.81 & AT \\
\hline 17 & Incorporates the use of ICT in the teaching and learning process & 3.54 & AT & 3.67 & AT \\
\hline 18 & $\begin{array}{l}\text { Encourages students to work together by promoting small group or } \\
\text { whole class activities }\end{array}$ & 3.35 & AT & 3.81 & AT \\
\hline 19 & $\begin{array}{l}\text { Poses questions that will allow students to critically think for } \\
\text { themselves and become independent learners }\end{array}$ & 3.69 & AT & 3.82 & AT \\
\hline 20 & $\begin{array}{l}\text { Uses visual and practical learning experiences that may apply in } \\
\text { the real world }\end{array}$ & 3.61 & AT & 3.84 & AT \\
\hline \multicolumn{2}{|r|}{ Assessment } & 3.55 & AT & 3.75 & AT \\
\hline 21 & $\begin{array}{l}\text { Understands required standards, curriculum frameworks and } \\
\text { assessments }\end{array}$ & 3.68 & AT & 3.80 & AT \\
\hline 22 & $\begin{array}{l}\text { Makes the assessment part a regular routine in class and not an } \\
\text { add-on activity only }\end{array}$ & 3.54 & AT & 3.68 & AT \\
\hline 23 & $\begin{array}{l}\text { Reacts to students' assessment results positively and use the } \\
\text { information to help them further }\end{array}$ & 3.62 & AT & 3.81 & AT \\
\hline 24 & $\begin{array}{l}\text { Designs a target-oriented assessment evaluating one or two } \\
\text { learning outcomes at a time }\end{array}$ & 3.39 & AT & 3.7 & AT \\
\hline 25 & $\begin{array}{l}\text { Utilizes various assessment tools in measuring the learning } \\
\text { outcomes }\end{array}$ & 3.54 & AT & 3.74 & AT \\
\hline \multicolumn{2}{|c|}{ Identification of Student's Needs } & 3.7 & AT & 3.81 & AT \\
\hline 26 & Understands the psychological and emotional issues of students. & 3.71 & AT & 3.80 & AT \\
\hline 27 & $\begin{array}{l}\text { Investigates problems and understand students' needs before } \\
\text { coming up with a decision and conclusion }\end{array}$ & 3.69 & AT & 3.79 & AT \\
\hline 28 & $\begin{array}{l}\text { Has the ability to consider the needs, views, beliefs and situations } \\
\text { of others }\end{array}$ & 3.74 & AT & 3.83 & AT \\
\hline 29 & $\begin{array}{l}\text { Pursues questions, goals, ideas and learning towards a conclusion } \\
\text { despite barriers and challenges }\end{array}$ & 3.67 & AT & 3.80 & AT \\
\hline 30 & $\begin{array}{l}\text { Observes students who possess talents in different areas like sports, } \\
\text { writing, speaking, dancing, music, etc. and provide opportunities to } \\
\text { develop these talents }\end{array}$ & 3.67 & AT & 3.85 & AT \\
\hline \multicolumn{2}{|r|}{ Communication } & 3.68 & AT & 3.81 & AT \\
\hline 31 & $\begin{array}{l}\text { Interacts with the students, parents, colleagues and other } \\
\text { stakeholders }\end{array}$ & 3.49 & AT & 3.87 & AT \\
\hline 32 & Attends clearly to questions asked in class. & 3.76 & AT & 3.80 & AT \\
\hline 33 & $\begin{array}{l}\text { Maintains a stable voice and mindful of the tone and pitch while } \\
\text { teaching }\end{array}$ & 3.64 & AT & 3.75 & AT \\
\hline
\end{tabular}


Table 2 ...continued

\begin{tabular}{|c|c|c|c|c|c|}
\hline \multirow{2}{*}{\multicolumn{2}{|c|}{ Items }} & \multicolumn{2}{|c|}{ China } & \multicolumn{2}{|c|}{ PH } \\
\hline & & \multirow{2}{*}{$\begin{array}{r}\text { Mean } \\
3.85\end{array}$} & \multirow{2}{*}{$\begin{array}{l}\text { Des. } \\
\text { AT }\end{array}$} & \multirow{2}{*}{$\frac{\text { Mean }}{3.79}$} & \multirow{2}{*}{$\begin{array}{l}\text { Des. } \\
\text { AT }\end{array}$} \\
\hline 34 & $\begin{array}{l}\text { Uses body language to communicate and reinforce lecture or class } \\
\text { discussion for better comprehension }\end{array}$ & & & & \\
\hline 35 & $\begin{array}{l}\text { Uses the skills in communication in dealing calmly a difficult } \\
\text { situation in teaching }\end{array}$ & 3.68 & AT & 3.86 & AT \\
\hline \multicolumn{2}{|r|}{ Collaboration } & 3.42 & AT & 3.71 & AT \\
\hline 36 & $\begin{array}{l}\text { Works together with parents, colleagues and other stakeholders for } \\
\text { a more conducive teaching and learning experience among the } \\
\text { students }\end{array}$ & 3.51 & AT & 3.74 & AT \\
\hline 37 & $\begin{array}{l}\text { Assists other teachers in their use of new teaching and learning } \\
\text { practices }\end{array}$ & 3.62 & AT & 3.75 & AT \\
\hline 38 & $\begin{array}{l}\text { Works in partnership with the community to promote student } \\
\text { development }\end{array}$ & 3.2 & OT & 3.72 & AT \\
\hline 39 & $\begin{array}{l}\text { Teams up with other colleagues to improve the overall image of } \\
\text { the school and the instruction that take place in it }\end{array}$ & 3.71 & AT & 3.72 & AT \\
\hline 40 & $\begin{array}{l}\text { Refers a student to other helping professionals or agencies for } \\
\text { further understanding of their behaviors }\end{array}$ & 3.05 & OT & 3.63 & AT \\
\hline \multicolumn{2}{|c|}{ Maintaining a Professional Appearance } & 3.77 & $\mathrm{AT}$ & 3.8 & AT \\
\hline 41 & $\begin{array}{l}\text { Displays maturity in class situations and other related educational } \\
\text { activities }\end{array}$ & 3.75 & AT & 3.76 & AT \\
\hline 42 & $\begin{array}{l}\text { Reviews own opinions, beliefs, thoughts, and attitudes based on } \\
\text { further information and experience }\end{array}$ & 3.7 & AT & 3.76 & AT \\
\hline 43 & $\begin{array}{l}\text { Understands roles and responsibilities as professionals in the } \\
\text { school setting. }\end{array}$ & 3.81 & AT & 3.83 & AT \\
\hline 44 & $\begin{array}{l}\text { Keeps a certain degree of professionalism when posting on a social } \\
\text { media platform. }\end{array}$ & 3.78 & AT & 3.84 & AT \\
\hline 45 & $\begin{array}{l}\text { Wears neat, clean clothes and projecting a professional look with a } \\
\text { clear distinction between a teacher and a student. }\end{array}$ & 3.81 & AT & 3.83 & AT \\
\hline \multicolumn{2}{|c|}{ Commitment to the Profession } & 3.54 & AT & 3.77 & AT \\
\hline 46 & $\begin{array}{l}\text { Conducts own research to test new approaches that may cultivate } \\
\text { learning }\end{array}$ & 3.20 & OT & 3.66 & AT \\
\hline 47 & $\begin{array}{l}\text { Desires for lifelong learning; that is continuous learning to uphold } \\
\text { professional efficiency and effectiveness }\end{array}$ & 3.77 & AT & 3.78 & AT \\
\hline 48 & Supports advocacies on human rights & 3.41 & AT & 3.78 & AT \\
\hline 49 & $\begin{array}{l}\text { Signifies service to other people and the entire learning community } \\
\text { as a whole }\end{array}$ & 3.51 & AT & 3.80 & $\mathrm{AT}$ \\
\hline 50 & $\begin{array}{l}\text { Imprints positive thoughts in the teaching and learning process as } \\
\text { well as life in general }\end{array}$ & 3.79 & $\mathrm{AT}$ & 3.82 & $\mathrm{AT}$ \\
\hline
\end{tabular}

Legend. Des. = Descriptions. 1.00 - 1.75 Never True to Me (NT), 2.51 - 3.25 Often True to Me (OT), 1.76 - 2.50 Seldom True to Me (ST), and 3.26-4.00 Always True to Me (AT).

\subsection{Relationship between the respondents' professional characteristics and their teaching competencies}

Table 3 presents the relationship between the respondents' professional characteristics that include educational preparation, benefits and privileges, and professional development opportunities and their teaching competencies. In China, it can be observed that educational attainment $(r=0.457, p<=0.039)$ and monthly salary $(r=0.298, p<0.038$ ) were found to be significantly correlated to teaching competencies. It indicates therefore that respondents who have graduate degrees have higher teaching competencies compared to those having bachelor's degree while those with higher salaries also have higher teaching competencies. Meanwhile, in Philippines, educational attainment $(r=0.192, p<0.05)$ and eligibility $(r=0.984, p<0.05)$ were the ones found to be significantly correlated to teaching competencies. It is comparable to the respondents in China that respondents who have graduate degree have higher teaching competencies compared to those who have not. In addition, board passer respondents have higher teaching competencies compared to those respondents who have either civil service or teaching certificate. 
Bagapuro, A., \& Delos Santos, M. R. H.

Table 3

Relationship between the respondents' professional characteristics and their teaching competencies

\begin{tabular}{lcccc}
\hline \multicolumn{1}{c}{ Professional Characteristics } & \multicolumn{2}{c}{ China } & Philippines \\
\cline { 2 - 5 } & Educational Preparation & $p$ & $r$ & $p$ \\
Educational Attainment & $0.457^{*}$ & 0.039 & $0.192^{*}$ & 0.048 \\
Eligibility & 2.785 & 0.098 & $0.984^{*}$ & 0.027 \\
Years of Experience & -0.21 & 0.187 & -0.247 & 0.079 \\
& Benefits and Privileges & & \\
Monthly Salary & $0.298^{*}$ & 0.038 & 1.753 & 0.078 \\
Overtime Pay & -2.986 & 1.076 & -3.701 & 1.087 \\
Bonuses/Allowances & -3.8 & 1.007 & -0.876 & 0.323 \\
Leave/Medical Privileges & -0.165 & 0.056 & 1.934 & 0.076 \\
& Professional Development Opportunities & & \\
Trainings & 1.555 & 0.102 & -0.276 & 0.162 \\
Scholarship Program & -0.378 & 0.899 & 1.287 & 1.004 \\
\hline
\end{tabular}

Note. $p<.05$.

\subsection{Difference between the teaching competencies of the respondents in the Philippines and China}

To determine whether there is a difference in teaching competencies between Filipino teachers working in the Philippines and in China, independent sample T-test was performed. Results show that statistically, there is a difference in terms of using varied teaching strategies $(t(161)=0.38, p<0.05)$, collaborating $(t(161)=0.29, p$ $<0.05)$, and demonstrating a commitment to the profession $(t(161)=0.29, p<0.05)$. It implies therefore that Filipino teachers teaching in the Philippines have higher teaching competencies in terms of the said parameters compared to those who are teaching in China.

\section{Table 4}

Difference between the teaching competencies

\begin{tabular}{lcccccc}
\hline \multirow{2}{*}{ Teaching competencies } & \multicolumn{2}{c}{ Mean } & \multirow{2}{*}{ MD } & \multirow{2}{*}{$t$} & $p$ \\
\cline { 2 - 3 } & China & PH & & & & \\
\hline Interacting well with students & 3.62 & 3.75 & & 0.13 & 1.234 & 1.034 \\
Creating a Learning Environment & 3.78 & 3.80 & & 0.02 & -0.612 & 1.096 \\
Good at Lesson Plan Design & 3.69 & 3.80 & & 0.11 & 2.753 & 0.381 \\
Able to Use Varied Teaching strategies & 3.41 & 3.79 & & $0.38^{*}$ & 1.087 & 0.027 \\
Able to Assess & 3.55 & 3.75 & & 0.20 & 2.001 & 1.265 \\
Able to Identify Student Needs & 3.70 & 3.81 & & 0.11 & 1.308 & 0.871 \\
Good at Communication & 3.68 & 3.81 & & 0.13 & 0.239 & 0.067 \\
Able to Collaborate & 3.42 & 3.71 & & $0.29 *$ & -1.804 & 0.035 \\
Maintaining a Professional Appearance & 3.77 & 3.80 & & 0.07 & -2.084 & 1.008 \\
Demonstrating a Commitment to the Profession & 3.54 & 3.77 & & $0.29 *$ & 0.407 & 0.046 \\
\hline \hline
\end{tabular}

Note. $p<.05$.

\section{Discussions}

Results of the professional characteristics and teaching competencies of Filipino teachers in China and Philippines were discussed thoroughly in this section. Differences were clearly noted and given further interpretation.

\subsection{Professional Characteristics}

Both Filipino teachers from China and Philippines are educationally prepared and eligible but differences in their educational background and eligibility were noted. Though all the respondents finished their bachelor's degree, many of those teaching in the Philippines are master's degree holders. In China, they are not required to pursue graduate programs to be promoted but rather more of an initiative of the teacher. In fact, due to heavy

72 Consortia Academia Publishing (A partner of Network of Professional Researchers and Educators) 
workload assignments, Filipino teachers in China do not have extra time in enrolling for advanced degrees, not unless it is an online course or through the Open University. Whereas in the Philippines, completing a post-graduate degree was essential especially when it comes to promotion and salary increase. For teachers to step up from Teacher 1 to Master teacher or even Head teacher, they should be at least a master's degree holder. In the study of Zulieta, Sudarsana, Arrieta, and Ancho (2020), it was found out that enrolment in the master's level decreased but is stable in the doctoral level in the last six academic years (2013-2014 to 2018-2019). Truly, teachers opt to enroll in the graduate level to remain enriching their competencies in the teaching profession. However, it was a departure in the findings of Naco (2015) that very few of the teachers obtained master's degree.

For eligibility, while many respondents in China teach with license, the number was still considerably low when compared to the Philippines. This was because China has a huge demand for foreign teachers and imposing stricter requirements and qualifications would discourage them to come. The demands and the difficulty in hiring foreign teachers pushed some schools to lower their qualification to even high school graduates for English native speakers and a bachelor's degree in any field for non-native speakers. Whereas in the Philippines, a stricter eligibility is imposed especially for teachers in public schools. As per DepEd Order No. 22, s. 2015, applicants for Teacher I position should possess a valid certificate of registration/professional license as a teacher from the Professional Regulation Commission. As Llego (2019) mentioned, teachers in public schools need to comply with the standards and qualification of the recruitment process for any teaching positions in kindergarten, elementary and junior and senior high school. Moreover, both teachers in China and Philippines has diverse teaching experience. Though teaching is said to be a difficult profession, the respondents opted to stay for years in this career.

China offers a more competitive salary to Filipino teachers even to under-qualified ones compared to the salary given to licensed teachers in the Philippines. The salary of those in China may vary every month when converted to Philippine currency because of some factors such as inflation rates, interest rates, political stability, and recession, but usually, it does not go below Php 20,000 pesos. For those in the Philippines, public school teachers are given a standard Salary Grade $11(\mathrm{PhP} 23,877.00$ as per Salary Standardization Law, Second Tranch) for Teacher 1 and increases as one's position also increases. On the other hand, salaries of those is private schools differ depending on the regulations of their respective institutions. It can be understood further that most of the Filipino teachers in China and the Philippines did not get paid for the extra hour of their work. In China, these were due to some factors like teachers are paid per class; they cannot complete the teaching hours required from them, or it is also possible that an agreement was made before signing the contract. In the Philippines, though Article III, Section 13 of Republic Act No. 4670 also known as the Magna Carta for Public School Teachers says that "where the exigencies of the service so require, any teacher may be required to render more than six hours but not exceeding eight hours of actual classroom teaching a day upon payment of additional compensation at the same rate as his regular remuneration plus at least twenty-five per cent of his basic pay", teachers no longer claim overtime pay since most of their overtime jobs are not related to actual classroom teaching but mostly accomplishing paper works, so they just prefer to do it at home.

Meanwhile, Filipino teachers in China receive leave and medical privileges while the majority of professional teachers in the Philippines do not get these privileges. In China, schools use the leave and medical privileges to attract foreign teachers especially Filipinos. All schools in China were mandated to provide medical insurance; it would only differ in the coverage. However, in the Philippines, the reason seen on this matter was that the respondents were mostly working for a private institution which has the power to decide on the leave and medical privileges of the teachers. Also, these private schools differ in providing the benefits other than what was mandated by law because of financial considerations.

\subsection{Teaching Competencies}

While all the ten (10) teaching competencies generated mean scores described as always true of me for both 
China and Philippines, scores of Filipino teachers from China were lower than that of the Philippines. Hence, all the respondents, regardless of their country of work, displayed potentialities and capabilities necessary for a teacher in the 21 st century. They are able to interact well with the students, create a learning environment, good at lesson planning, able to use varied teaching strategies, assess, collaborate and identify student's needs, good at communication, can maintain a professional appearance and can demonstrate a commitment to the teaching profession.

Of these competencies, creating a learning environment obtained the highest mean among those who were in China. As suggested by Clapper (2010), a safe learning environment asks teachers to keep their classroom psychologically safe by setting the stage for learning, emphasize respectful communication, model mutual support and respectful communication and express the importance of confidentiality in learning. This was the same as the findings of Ozerem and Akkoyunlun (2015) that the interaction between the learners and their learning environment could provide them with meaningful experiences toward the teaching-learning process. Despite several barriers such as language, differences in culture and limitations of their role as a foreign teachers, they create an environment conducive for teaching and learning and promotes the full development of students as individuals without discrimination to race, ethnicity, sex, socio-economic status, abilities or disabilities.

On the other hand, identification of student's needs and communication were the competencies which has the highest mean among teachers in the Philippines. Teachers were trained to diverse situations and exposed to different strategies in assessing the needs of their students be in academic, personal or emotional aspects. As mentioned by Villar (2009), the teacher communicates with the students on an almost daily basis and in a best position to establish a relationship based on mutual trust and respect. Therefore, teachers could immediately look into student's concern and provide appropriate action if necessary. In addition, being a listener-advisor is one of the roles of a teacher. Students confide to them and ask for advice (Villar, 2009). Moreover, because teachers in the Philippines do not struggle in the use of language, communication has become easy not only for the students but also to other stakeholders as well. They had the language to express and convey the message they want; they were trained on how to deal and communicate effectively to parents and students with respect and without judgment. Unlike in China, communication was the biggest and most common challenge of foreign teachers. Most Chinese do not speak in English especially the suburban areas of the country. Filipino teachers unable to speak the language remained dependent on Chinese English teachers. Chinese teachers usually translate everything for the Filipino teachers not unless they had studied the language and able to communicate in Mandarin.

Collaboration has the lowest mean among all competencies both for China and Philippines, though teachers from the Philippines has higher mean compared to teachers in China. Filipino teachers in China had limited function. Their job was just confined in four walls of their classrooms. Moreover, most of the time they were not part in coming up solutions to problems related to schools and students. When their students pose behavioral issues, they can only refer them to their Chinese counterpart or the supervisor and headmaster. In the Philippines, teachers were very much involved in the solution and decision making with regard to the students and other educational concerns. They can collaborate with people within and out of the system to address various issues. They had the support of the school and the community, particularly the local government unit. It was seen that teachers were not alone in making the lives of the students meaningful and fruitful in their journey into becoming a productive citizen of the country.

\subsection{Relationship between the respondents' professional characteristics and their teaching competencies}

Educational attainment had a high significant relationship to teaching competencies for both respondents in China and Philippines. It shows that Filipino teachers with graduate degrees seemed to be more competent teachers compared to the one with a bachelor's degree. They were confident in the teaching profession because of the acquired new knowledge and skills primarily from their advanced studies. Continuous learning is indeed an important skill necessary for teachers since this does not only upgrade the knowledge about their respective

74 Consortia Academia Publishing (A partner of Network of Professional Researchers and Educators) 
subject areas but also their proficiency in the teaching and learning process. The result of the study affirmed the findings of Tucker (2013) that teachers who completed their graduate degrees had renewed interest in their profession and were equipped with new approaches, strategies, and knowledge relevant to their subjects which can be applied to their teaching styles.

Corollary to this, those who are licensed professional teachers teaching in the Philippines have higher competencies since they have undergone professional preparation by passing the licensure examination. According to the National Research Council (2001), there is a belief that testing can improve the quality of the teaching force because of the assumption that tests are good measures of the competencies needed for effective teaching. Hence, the Professional Regulation Commission (PRC) of the Philippines identify teachers who passed the Licensure Examination for Teachers (LET) as professional teachers equipped with theoretical knowledge in education, skills, strategies and techniques and qualities of a professional teacher. On the other hand, higher salaries received also mean higher teaching competencies for those who are teaching in China. The teachers are greatly inspired and motivated to teach at their best because of the remuneration that they receive. Since they are paid well, they exert their full effort in terms of their teaching performance.

\subsection{Difference between the teaching competencies of the respondents in the Philippines and China}

Filipino teachers teaching in the Philippines seemed to possess higher teaching competencies in terms of use of varied teaching strategies, collaboration with students and other stakeholders and commitment to the profession compared to those who are teaching in China. This is attributed to the fact that teachers in the Philippines have a set of established standards drafted by the different and integrated government and non-government agencies particularly the Department of Education (DepEd), Teacher Education Council (TEC), Professional Regulation Commission and Technical Education and Skills Development Authority (TESDA). In this manner, teachers are consistently monitored and evaluated in their performance and are given professional development opportunities that are mostly funded by the institutions where they belong. The Philippines has also begun the national adoption and implementation of the Philippines Professional Standards for Teachers (PPST) which assures that teachers are competent professional educators.

Moreover, foreigners with a bachelor's degree and fluent in spoken English are eligible to teach in China. This is in accordance to the minimum requirement for foreign teachers from the Ministry of Education and State Administration of Foreign Experts Affairs (SAFEA) of the People 's Republic of China. Filipinos who meet the minimum requirements in China can technically work as a teacher without having the professional preparation or proper teaching certification that would prove competence for the teaching job. Most of the teachers including Filipino teachers sought teaching certification online such as the 120 hours such as Teaching English to Speakers of Other Languages and Certificate or Teaching English as a Foreign Languages.

\section{Conclusions}

In view of the findings, several conclusions were drawn. Educational preparation serves a vital role for Filipino teachers to become competent in the teaching profession. Having a master's degree is an essential component of professional development, whether teaching abroad or in the country. Same true with eligibility. Having professional licenses make them more competent and competitive in their teaching jobs. As such, even those who are not education graduates but chose to teach opted to take the LET especially that teaching is a lifelong profession. Furthermore, benefits and privileges, particularly salary in the Philippines is not as competitive as that of China even if teachers possess minimum educational preparation. High salaries prompted Filipinos to practice teaching in that country. Also, professional development opportunities such as trainings and scholarships programs are well-enjoyed by teachers teaching in the Philippines. Educational institutions are supportive of professional needs of the teachers. Finally, teachers in the Philippines have higher teaching competencies because they are well educationally prepared and are given varied opportunities for learning. 
Bagapuro, A., \& Delos Santos, M. R. H.

Acknowledgement: The authors would like to extend their deepest gratitude to Dr. Florante P. Ibarra and Dr. Leila M. Collantes, members of the Advisory Committee for their approval of this research paper. Their expertise, suggestions, and feedback made this study more relevant, timely and meaningful. Also, to Dr. Edwin Ibañez for doing the statistical analysis.

\section{References}

BusinessMirror. (2018). Filipino teachers as world class educators. https://businessmirror.com.ph/2018/03/13/filipino-teachers-as-world-class-educators

Clapper, T. (2010). Creating the safe learning environment. PAILAL, 3(2), 1-6.

DepEd Order No. 22, series 2015. (2015). Hiring guideline for the remaining positions effective school year (SY) 2015-2016. https://www.deped.gov.ph/2015/06/02/do-22-s-2015-hiring-guidelines-for-the-remaining-teaching-posit ions-effective-school-year-sy-2015-2016/

Llego, M. A. (2019). 2019 Requirements for DepED teacher applicant. https://depedtambayan.net/requirements-deped-teacher-applicant/

Marzano, R. J., \& Marzano, J. S. (2003). The key to classroom management. Educational Leadership: Journal of the Department of Supervision and Curriculum Development, 61(1), 6-13.

Naco, P.L. (2015). Competencies and anxiety in teaching mathematics among elementary school teachers in the $K$ to 12 curriculum in the Division of San Jose City [Unpublished doctoral dissertation]. Central Luzon State University, Science City of Munoz, Nueva Ecija, Philippines

National Research Council. (2001). Testing teacher candidates: The role of licensure tests in improving teacher quality. The National Academies Press. https://doi.org/10.17226/10090

Ozerem, A., \& Akkoyunlu, B. (2015). Learning environments designed according to learning styles and it's effects on mathematics achievement. https://doi.org/10.14689/ejer.2015.61.4

Rice, J. K. (2003). Teacher quality: Understanding the effectiveness of teacher attributes. https://www.epi.org/publication/books_teacher_quality_execsum_intro/

Shukla, S. (2014). Teaching competency, professional commitment and job satisfaction: A study of primary school teachers. IOSR Journal of Research and Method in Education, 4(3), 44-64. https://doi.org/10.9790/7388-04324464

The LawPhil Project. (n. d.). The magna carta for public school teachers. https://lawphil.net/statutes/repacts/ra1966/ra_4670_1966.html

Tucker, J. (2013). Graduate programs in educations: Impact on teachers' careers. https://files.eric.ed.gov/fulltext/EJ1017213.pdf

Villar (2009). Implementing a comprehensive guidance and counseling programs in the Philippines. Aligned Transformations. Philippines

Zeiger, S. (2018). List of core competencies for educators. https://work.chron.com/list-core-competencies-educators-8916.html

Zulieta, N., Sudarsana, I., K., Arrieta, G., \& Ancho, I. (2020). Trends in school enrollment and graduation: The experience of educational management students in the graduate school. Jurnal Penjaminan Mutu, 6. 88. https://doi.org/10.25078/jpm.v6i1.1302 